\title{
Coparenting in Stepfamilies: Maternal Promotion of Family Cohesiveness with Partner and with Father
}

\author{
Nicolas Favez $\cdot$ Eric D. Widmer • \\ Minh-Thuy Doan $\cdot$ Hervé Tissot
}

Published online: 22 January 2015

(c) Springer Science+Business Media New York 2015

\begin{abstract}
Coparenting refers to the support parents bring to each other when rearing a child. Supportive coparenting ensures cohesiveness of the family, which is linked with child outcomes. Little is known, however, about the coparental relationship in stepfamilies between the custodial parent, usually the mother, and the new partner, and how it compares to coparenting with the father. This study addressed mother-reported coparenting in stepfamilies and also compared it with that in first-marriage families. Three dimensions of coparenting were considered: family integrity, disparagement, and conflict. Mothers $(N=300)$ completed questionnaires on their coparenting relationship with the father and with the partner, marital satisfaction, and attachment. Half the mothers were living in a stepfamily with a child between 5 and 13 years old from a previous marriage, and half in a first-marriage family. The main results show that (a) mothers promote family integrity in stepfamilies either with the partner, or with the father, but not with both; (b) the older the child, the less the mothers reported integrity with the father in both families, and the more they reported disparagement against the partner and conflict with the partner in stepfamilies; and (c) maternal marital satisfaction is linked with all dimensions of coparenting with the father in first-marriage families, but only with disparagement against the partner and conflict with the partner in stepfamilies. Overall,
\end{abstract}

N. Favez $(\bowtie) \cdot H$. Tissot

Faculty of Psychology and Educational Sciences, University

of Geneva, Boulevard du Pont d'Arve 40, 1211 Geneva 4,

Switzerland

e-mail: nicolas.favez@unige.ch

E. D. Widmer · M.-T. Doan

Faculty of Social Sciences, University of Geneva, Geneva, Switzerland coparenting has similar characteristics in both types of families, but also presents differences that should be considered when working with parents who are committed to a new relationship.

Keywords Coparenting - Stepfamilies · Family cohesiveness $\cdot$ Marital satisfaction $\cdot$ Attachment

\section{Introduction}

Coparenting refers to the specific function of the parents' relationship that is centered on the child (Belsky et al. 1995; McHale 2007). Minuchin (1974) defined coparenting as the executive system of the family, namely, the core relational process around which family functioning is organized and which is responsible for the cohesiveness of the family over time. Disturbances in the coparental relationship have a detrimental impact on the social and cognitive development of the child, as early as in the first years of life (see Teubert and Pinquart 2010, for a meta-analysis). In particular, the child is more likely to present internalized and externalized symptoms (McHale and Rasmussen 1998; Schoppe et al. 2001), a lower level of adaptation at school (Dopkins Stright and Neitzel 2003; McHale et al. 2000), less competence in peer relationships (Leary and Katz 2004), or a slower development of theory of mind (Favez et al. 2012). As a consequence, coparenting has now become a specific target of intervention for family therapists and educators (Feinberg and Sakuma 2011; Frascarolo et al. 2011).

Coparenting has mainly been studied in first-marriage families with biological children, and its definition was first restricted to the relationship between the parents. However, it has been now acknowledged that coparenting dynamics 
concern any adults collaborating to raise children, and it is a critical issue in all forms of families. The use of the concept of coparenting has thus been expanded beyond the parental dyad to include other dyads (e.g., single mother and grandmother), the emphasis being on the relational processes between the two adults rather than on the partners per se (Baker et al. 2010; McHale et al. 2002a). In stepfamilies, there are at least two dyads of adults directly involved with the child: the custodial parent-noncustodial parent dyad and the custodial parent-stepparent dyad. Although studies have shown the importance of the collaboration between the divorced parents, less attention has been brought to the coparenting relationship between parents and stepparents (Adamsons and Pasley 2006; Van Eeden-Moorefield and Pasley 2013). One of the main questions is how the custodial parent-most often the mother-ensures family cohesiveness when, from the child's perspective, there are two family "nuclei": the new family, which needs to build its own cohesion, and the former family, which is still fully significant for the child (Emery 2012).

Support between the parents, at an emotional and instrumental level, is the core dimension of family cohesiveness. It refers to a common perspective between the parents, the expression of affection and warmth between them, the reciprocal validation of their respective parenting behaviors, and the help they bring to each other in the daily tasks relative to the rearing of the child (Feinberg 2003; Margolin et al. 2001; McHale 1997; Van Egeren and Hawkins 2004). An enduring conflict between the parents is, in contrast, a coparenting dimension related to the dissolution of cohesiveness. It refers to the open expression of hostility between the parents, competition, undermining, or mutual disparagement. As a result, the child may be entrapped in the parental conflict as a go-between, a position that is especially detrimental for a child's development (Minuchin et al. 1978). Interestingly, although it was first postulated that support and conflict were mutually exclusive (Minuchin 1974), they were later understood to be distinct dimensions that may be simultaneously present in a given coparental subsystem (Teubert and Pinquart 2010).

Studies in first-marriage families have shown that the promotion of family cohesiveness is influenced by several variables. One of its most consistently reported determinants is the quality of the marital relationship, often assessed in terms of marital satisfaction: The more parents are satisfied with their marital relationship, the more they support each other in their coparental tasks (Frosch et al. 1998; Margolin et al. 2001; Van Egeren 2003). On the other hand, marital dissatisfaction is linked to hostile coparenting or to withdrawal of one of the parents from the coparental relationship (Belsky and Hsieh 1998;
Schoppe-Sullivan et al. 2004). As a consequence, the quality of the marital relationship is thought to foreshadow the coparental relationship (Cowan and Cowan 1992; Lewis 1989).

Parents' personalities also influence their aptitude to support each other (Kolak and Volling 2007; Talbot and McHale 2004; Van Egeren 2003). In particular, individual relational models such as attachment models are closely related to coparenting (Beaton et al. 2013; Cowan et al. 2009). Attachment involves approach/avoidance tendencies and the ease with which an individual cooperates with others through the interplay of avoidance and anxiety (Bartholomew and Horowitz 1991; Hazan and Shaver 1987). Avoidance refers to the tendency to repress emotional needs, to feel discomfort in close relationships, and to maintain a distance from others. In consequence, avoidant people are more likely to reject cooperation with others and are less prone to build a "relational unit" with their partner. Anxiety refers to the tendency to feel uncertainty and helplessness in close relationships. Anxious people try to "force" other people to react and pay attention to them, and so they overemphasize their needs and their helplessness. Cooperation may thus be hampered by the constant demands that anxious individuals make on their partners, which may fuel conflicts between them (Mikulincer and Shaver 2007; Shaver and Mikulincer 2002a, b). Avoidance and anxiety are thus predictive of conflict, lower cohesion, and negativity in coparental interactions (Paley et al. 2005; Sheftall et al. 2010; Talbot et al. 2009).

Finally, several studies have shown that coparenting also varies according to the characteristics of the children, such as gender, although data are inconsistent: Some studies show that coparental conflict may be exacerbated with boys (Favez et al. 2006; McHale 1995; McHale et al. 2002b), whereas others show the same with girls (Stroud et al. 2011). Children's age must also be taken into account, as the function of coparenting changes over time: Promoting family cohesiveness is less prominent when children grow older and the promotion of individuation comes to the fore (Teubert and Pinquart 2011).

The interrelations between marital and coparental relationships have been at the core of the conceptualizations of coparenting. However, when the couple divorces, this interdependence is broken up. Former spouses no longer have a marital relationship, but they must still maintain a coparenting relationship, the quality of which is crucial for the child. Although there is no longer a shared household, there continue to be shared relations between the members of the divorced family and cohesiveness must still be ensured (Emery 2012). Children whose parents engage in supportive coparenting post-divorce indeed have better outcomes (Adamsons and Pasley 2006; Amato et al. 1995; Papernow 2013; Pasley and Garneau 2012; Whiteside and 
Becker 2000). On the other hand, an enduring post-divorce conflict between the parents hampers coparenting, with negative consequences for the children (Hetherington and Stanley-Hagan 2002; Maccoby and Mnookin 1992; Pasley and Garneau 2012). Moreover, when the conflict is high, the noncustodial parent tends to disengage from the relationship with the children (Amato 1999; Amato and Rezac 1994; Falci 2006; Holroyd and Sheppard 1997). As is the case in first-marriage families, personality variables influence the ability of the parents to renegotiate their coparental relationship after divorce. Studies have shown that parents with a secure attachment tend to preserve a supportive coparenting relationship (Dozier et al. 1993; Roberson et al. 2011) and, in turn, supportive coparenting strengthens the relationship between ex-spouses (MaddenDerdich and Arditti 1999).

The situation becomes even more complex when the parents begin a new relationship, as they will need to deal with a "double agenda": on the one hand, to build cohesiveness for their new families-including the child of a previous relationship - and on the other to maintain coparental cohesiveness with their former spouse, the parent of the child. Little is known about the way that parents manage this situation. Systematic comparisons of coparenting with the ex-spouse and with the current partner in stepfamilies have rarely been done. Studies have, however, highlighted the deep interdependence of the different relational systems in stepfamilies. The relationship between stepchildren and the stepparent has thus been shown to be cardinal for the quality of the new parentstepparent relationship (Bray and Kelly 1998; Ganong et al. 1999; Vogt Yuan and Hamilton 2006). There is also a gender effect: The relationship between stepson and stepfather has been reported to be easier to build than the relationship between stepdaughter and stepfather. A stronger relationship may, in turn, facilitate the coparental relationship between the mother and her new partner (Visher et al. 2003). An association has also been shown between the quality of communication between the former spouses and the relational satisfaction they get from their relationship with their new partner (Braithwaite et al. 2003; Schrodt 2010). Furthermore, studies have shown that a change in the status of the noncustodial parent (the father has a child with his new partner, for example) implies a decrease in the amount of coparenting with the custodial parent (Amato et al. 2009; McGene and King 2012).

Several questions nonetheless remain unanswered. First, and most important, is the following: To what extent is the promotion of the new family cohesiveness by the custodial parent exclusive of or complementary to maintaining a sense of family with the other parent? In this regard, it is important to investigate whether coparenting in this situation has the same determinants as in first-marriage families.
Knowing more about coparenting processes not only between divorced parents, but also between the parents and their new partners, is all the more important considering that the pressure for parents to cooperate is likely to increase in the near future. The number of stepfamilies is increasing and at the same time, ex-spouses are more often choosing joint custody as a post-divorce arrangement in the United States, as well as in several European countries (Bjarnason and Arnarsson 2011; Gately et al. 2006). Moreover, although stepparents do not have a legally recognized role toward the child, their "parental" role may still be significant and of increasing importance.

In order to answer these questions, we conducted a study whose aim was to explore mother-father and motherpartner coparenting in stepfamilies, with an emphasis on cohesiveness-promoting coparenting behaviors and on conflictive behaviors. We also compared mother-father coparenting in stepfamilies with that in first-marriage families. We assessed, on the one hand, the influence of the mother's attachment and marital satisfaction on coparenting, and, on the other, the influence of the age and gender of the child on coparenting. We addressed this set of issues from the perspective of mothers who have had sole custody rights, as this is representative of the situation in a large majority of cases in Switzerland to date.

\section{Method}

\section{Participants}

Mothers $(N=300)$ lived in households with children who were between 5 and 13 years old. They were volunteer participants from a random sampling of the state population, contacted by a polling institute. Half of the families (150) were stepfamilies and were included in the study according to the following criteria: mothers live with a partner (married or cohabitant), they have at least one child from a previous marriage living in the household, and the custody rate is $40 \%$ of the time or more. The other half of the families were first-marriage families, included according to the following criteria: mothers live with the father of their child (married or cohabitant), there is at least one child living with them, and none of the parents has children from a previous marriage. Families of both groups were matched for age of the first child and socioeconomic status. Of the 150 children in stepfamilies, 79 were girls and 71 were boys. Of the 150 children in first-marriage families, 72 were girls and 78 were boys.

Statistics for the sample characteristics are provided in Table 1. On average, there were 2.1 children $(S D=.9)$ in stepfamilies (minimum 1, maximum 5) and 2.4 children $(S D=.8)$ in first-marriage families (minimum 1 , 
Table 1 Means for the sample characteristics (standard deviations in parentheses)

\begin{tabular}{lccc}
\hline Demographic variable & $\begin{array}{l}\text { Total } \\
(N=300)\end{array}$ & $\begin{array}{l}\text { First marriage } \\
(N=150)\end{array}$ & $\begin{array}{l}\text { Stepfamilies } \\
(N=150)\end{array}$ \\
\hline $\begin{array}{l}\text { Children's characteristics } \\
\text { Age (years) }\end{array}$ & $10.17(2.01)$ & $10.06(1.98)$ & $10.27(2.05)$ \\
Time with custodial parent (\%) & - & - & $85.2(17.3)$ \\
Mother's/couple's characteristics & $10.6(5.2)$ & $14.4(4.9)$ & $6.7(4.5)$ \\
Duration of current relation (years) & 63.7 & 93.3 & 34 \\
Currently married (\%) & - & - & $7.4(4.2)$ \\
Duration of previous marriage (years) & - & - & $7.5(5.9)$ \\
Time since separation (years) & & & \\
\hline
\end{tabular}

from 1 (almost never) to 7 (almost constantly), a mean score being computed for each dimension. The questionnaire includes a fourth dimension, "affection," which was not retained for our study, as it is related to gestures of affection such as touching, which is unlikely to happen between stepfather and stepchildren.

Marital Adjustment Test (Locke and Wallace 1959; French Version by Wright and Sabourin 1985)

In this test, 15 items relative to the couple relationship are evaluated on scales with various metrics and different weights. Item 1 is about the degree of happiness and is evaluated on a 7-point scale with the scores 0 (very unhappy), 2, 7, 15, 20, 25, and 35 (perfectly happy). Items 2 to 9 relate to the agreement between spouses about topics such as sexual relations or family finances and are evaluated on a 6-point scale from "always agree" (with scores varying from 5 to 15$)$ to "always disagree" (0). Items 10 to 15 relate to topics such as conflict resolution or common leisure and are forced-choice questions with three or four possible answers for scores ranging from 0 to 15 . The total score ranges from 2 to $158(\alpha=.78)$; the higher the score, the more the person is satisfied. A cut-off score of 100 has been established, below which the relationship is considered to be distressed.

\section{Adult Attachment Questionnaire (Simpson 1990; French Version by Bouthillier et al. 1996)}

Ten items are assessed in this questionnaire on 7-point Likert scales ranging from 1 (strongly disagree) to 7 (strongly agree). Examples of items: "I find it relatively easy to get close to others"; "I don't like people getting too close to me"; "I find it difficult to trust others completely." Two indexes are obtained by computing the mean of the five items related to the indexes (Simpson et al. 1992): an avoidance/secure index $(\alpha=.79)$ and an anxiety index $(\alpha=.46)$. Higher scores reflect greater avoidance and greater anxiety, respectively. We performed an item-total correlation analysis for the anxiety dimension in order to about the child, in the child's presence?" Each item is rated 
find the item(s) responsible for the low consistency, but whatever the suppressed items were, the internal consistency stayed low, between .36 and .44. The anxiety dimension was thus not included in subsequent analyses.

A series of questions were asked about the number of days the child is at home in stepfamilies, the marital status of the mothers, their socioeconomic status (education and occupation), the duration of their current partnership, and the time since separation/divorce in stepfamilies.

\section{Statistical Analyses}

A full set of descriptive statistics (including mean and standard deviation) was computed for all variables of the study. Coparenting dimensions (family integrity, disparagement, and conflict) between the two groups of families and within stepfamilies were compared through independent samples and paired-sample $t$ test procedures. Linear mixed models were then used to test the influence of the determinants of coparenting (children's age and gender, maternal marital satisfaction, and attachment avoidance) for each coparent of the mothers (fathers in stepfamilies, partners in stepfamilies, and fathers in first-marriage families). Three models were tested (one for each dimension of coparenting). The "coparent" variable was entered as a categorical predictor along with child gender, whereas age of the child, marital satisfaction, and avoidance were entered as covariates. Main effects were tested for these five predictors. Moreover, four interactions between the coparent variable and the other determinants of coparenting were included in the model in order to test whether child gender and age, marital satisfaction, and avoidance had differential effects on the mothers' coparenting with different partners. In the present study, the data for stepfamilies were nested (the mother assessing coparenting with both the biological father of the child and her partner), whereas only one observation was available in first-marriage families. As statistical procedures available to analyze nested data such as multilevel analyses cannot be used when there is a different number of nested levels within each group (two in stepfamilies and one in first-marriage families), we had to treat the data for each coparent as independent. Thus, in order to limit the bias of ignoring the dependence of the data in stepfamilies, we chose to randomly split the stepfamily sample into two subgroups of $n=75$ each (there is no difference according to age and gender of the child or socioeconomic status between the two subgroups). We then used the mother-father coparenting data from one subgroup and the mother-partner data from the other. Therefore, the data included in the linear mixed models concerning the father and the partner in stepfamilies did not come from the same families. Post hoc tests were performed as a last step in the analyses for the significant predictors in order to investigate differences across coparental dyads.

\section{Results}

As a preliminary step, socio-demographic variables were tested against coparenting in both groups of families (marital status, socioeconomic level, duration of relationship, time since separation, duration of first marriage, and custodial rate in stepfamilies). Two links are significant, both in relation to stepfamilies: The duration of the first marriage is negatively correlated with disparagement of the father $(r=-.29, p<.01)$ and the custodial rate is negatively correlated with the promotion of family integrity with the father $(r=-.21, p<.05)$.

Descriptive statistics are provided in Table 2. Regarding coparenting, data show that mothers report overall more family integrity than they do conflict or disparagement in both types of families.

Several differences between families were observed. First, independent sample comparisons show that there is more family integrity, as well as more disparagement and conflict, with the father in first-marriage families than in stepfamilies. There is also more coparenting on the three dimensions with the father in first-marriage families than with the partner in stepfamilies. Finally, there is a withinfamily effect in stepfamilies: Paired sample comparisons show that there is more coparenting with the partner for family integrity and conflict, and there is more disparagement against the father than against the partner. Regarding the links between the coparenting behaviors of mothers in stepfamilies, family integrity with the father is not correlated with family integrity with the partner $(r=.11, n s)$, and conflict with fathers is not correlated with conflict with the partner $(r=.00, n s)$. There is, however, a positive correlation for disparagement $(r=.19, p<.05)$ which, while of low amplitude, shows that mothers who do disparage the father also disparage the new partner.

Regarding marital satisfaction, data show that the scores are on average above the cut-off of 100 for most of the mothers (see Table 2). However, $17 \%$ of the mothers $(n=25)$ in stepfamilies report a satisfaction below this cut-off, which is also the case for $25 \%$ of the mothers $(n=37)$ in first-marriage families. Independent sample comparison shows that satisfaction is significantly higher in stepfamilies.

Finally, attachment avoidance has an average mean (mean $=3.59, S D=.86$ ); there is no difference between the two groups of families for this dimension.

We then tested which variables were predictive of coparenting, taking into account potential variability in the significance of these predictors according to the coparent. 
Table 2 Descriptive data and means for marital adjustment, attachment, and coparenting in first-marriage families and in stepfamilies (standard deviations in parentheses)

\begin{tabular}{|c|c|c|c|c|c|c|c|c|}
\hline \multirow[t]{2}{*}{ Variables } & \multirow{2}{*}{$\begin{array}{l}\text { Total } \\
(N=300)\end{array}$} & \multirow{2}{*}{$\begin{array}{l}\text { Normal } \\
\text { range }\end{array}$} & \multirow{2}{*}{$\begin{array}{l}\text { First marriage } \\
(N=150) \\
\text { (1) With father }\end{array}$} & \multicolumn{2}{|c|}{ Stepfamilies $(N=150)$} & \multicolumn{3}{|c|}{$t$ test $(d f=297)$} \\
\hline & & & & $\begin{array}{l}\text { (2) With } \\
\text { father }\end{array}$ & $\begin{array}{l}\text { (3) With } \\
\text { partner }\end{array}$ & $(1) /(2)^{a}$ & $(1) /(3)^{a}$ & $(2) /(3)^{b}$ \\
\hline \multicolumn{9}{|l|}{ MAT } \\
\hline Marital adjustment & $114(21)$ & $>100$ & $109(21)$ & - & $118(21)$ & - & $-3.43 * * *$ & - \\
\hline $\begin{array}{l}N \text { below cut-off } \\
A A Q\end{array}$ & - & - & $37(24.7 \%)$ & - & $25(16.7 \%)$ & - & - & - \\
\hline Avoidance & $3.59(.86)$ & - & $3.64(.78)$ & - & $3.54(.94)$ & - & 1.02 & - \\
\hline \multicolumn{9}{|l|}{ Coparenting } \\
\hline Integrity & $3.5(1.0)$ & - & $4.6(.8)$ & $2.3(1.1)$ & $3.9(1.0)$ & $20.2 * * *$ & $6.4 * * *$ & $-13.7 * * *$ \\
\hline Disparagement & $2.1(.8)$ & - & $2.2(.8)$ & $1.9(.8)$ & $1.7(.8)$ & $2.6^{*}$ & $5.4 * * *$ & $3.2 * *$ \\
\hline Conflict & $2.0(.7)$ & - & $2.6(.9)$ & $1.3(.5)$ & $2.0(.8)$ & $15.9 * * *$ & $6.0 * * *$ & $-9.8 * * *$ \\
\hline
\end{tabular}

$M A T$ marital adjustment test, $A A Q$ Adult Attachment Questionnaire

$* p<.05 ; * * p<.01 ; * * * p<.001$

a Independent sample comparisons

${ }^{\mathrm{b}}$ Paired sample comparisons

Table 3 Tests of the fixed effects of children's characteristics, marital satisfaction, and attachment on coparenting integrity, disparagement, and conflict according to the coparent $(N=300)$

$* p<.05 ; * * * p<.001$

We tested linear mixed models, with child age and gender, marital satisfaction, and attachment avoidance predicting coparenting integrity, disparagement, and conflict. The results of the tests of the fixed effects can be found in Table 3.

The results showed that, first, in accordance with the bivariate tests, there is an effect of the coparent on family integrity. Moreover, integrity is also predicted by the age of the child: The older the child, the less the mother promotes the family unit. Post hoc tests showed that this effect of age was significant for integrity with the father in first-marriage families, $b=-.09, t(150)=-2.73, p<.01$, as well as with the father in stepfamilies, $b=-.14, t(75)=-2.00$, $p<.05$, but that it was not significant for the partner, $b=-.08, t(75)=-1.58, p=12$. The estimate for the interaction coparent $\times$ marital satisfaction was also significant. Post hoc tests revealed that higher marital satisfaction of the mother significantly predicted higher integrity with the father in first-marriage families, $b=.01$, $t(150)=3.30, p<.01$, whereas this effect was not significant in stepfamilies. This link was similar for the partner, albeit not significant, $b=.01, \quad t(75)=1.32$, $p=.19$. Finally, this link went in the opposite direction with the father in stepfamilies, with higher marital satisfaction in mothers predicting lower integrity with the father, although the link was not significant, $b=-.01$, $t(75)=-1.11, p=.27$. The difference between these links for fathers in first-marriage families and for fathers in stepfamilies was significant, $b=-.02, t(300)=-2.71$, $p<.01$.

The results confirmed that there is an effect of the coparent on disparagement. A second significant main effect 
showed that higher maternal marital satisfaction globally predicts lower disparagement. This effect, however, was not significant for the fathers in stepfamilies, $b=.00$, $t(75)=-.56, p=.58$. Differential effects according to the coparent were found concerning the age of the child. Post hoc tests showed that disparagement against the father in stepfamilies became lower as the child got older up, $b=$ $-.11, t(75)=2.33, p<.05$, whereas this effect was not found for fathers in first-marriage families. In contrast, the age of the child predicted higher disparagement against the partner, although this effect was only marginally significant, $b=.07, t(75)=1.83, p=.07$. Thus, the effect of the coparent $\times$ age interaction on disparagement was mainly due to the effect of the age of the child on disparagement in stepfamilies: As the child grows up, disparagement against the father tends to be lower, whereas disparagement against the partner tends to be higher. Another main effect approached-but failed to reachsignificance in first-marriage families: Avoidance was associated with more disparagement, $b=.16, t(300)$, $p=.06$.

Finally, confirming the results of the bivariate tests, there was a main effect of the coparent on conflict. In addition, higher marital satisfaction globally predicted lower conflict, as the main effect for marital satisfaction was significant. Post hoc tests showed that this effect was strong in first-marriage families, $b=-.01, t(150)=$ $-3.75, p<.001$, and with the partner in stepfamilies, $b=-.01, t(299)=-3.18, p<.01$, whereas it was of smaller amplitude and not significant with the father in stepfamilies, $b=.00, t(74)=-.75, p=.46$. Finally, the interaction term coparent $\times$ age of the child was significant: The age of the child was not linked to conflict with the father in first-marriage families or with the father in stepfamilies, but it predicted higher conflict with the partner, with conflict being higher as the child got older, $b=.12, t(75)=3.01, p<.01$.

\section{Discussion}

The aim of this study was to explore maternal promotion of family cohesiveness in stepfamilies through the coparenting behaviors of conflict, disparagement, and promotion of family integrity. Our results show, first, that in these families, coparenting behaviors are in general more frequent between the mother and her partner than between the mother and the father. This indicates that building family cohesiveness is indeed active in stepfamilies, households that include a child and a partner who are neither biologically nor legally related to one another. Moreover, family cohesiveness is still active between the ex-spouses, the mother and the father of the child: Mothers tend to preserve a sense of unity with their former families. However, promotions of family integrity with the father and with the partner are only weakly correlated, so that it is possible to speculate on two different organizations in stepfamilies: one in which there is an imbalance of coparenting functioning toward the "inside" of the new family, with an emphasis on stepfamily cohesiveness, and the other with an imbalance toward the "outside" of the new family, with an emphasis on the former family cohesiveness. As a consequence, it seems that mothers do not try to build a "supraordinated" cohesiveness that includes both their former and their current families. There are also differences for the two conflictive dimensions of coparenting, but not in the same direction: Mothers disparage the father more than they do the partner, which may be a remnant of the disputes between ex-spouses. On the other hand, more frequent conflicts occur with the partner than with the father, which may be due to management of daily life. Although all dimensions of coparenting are active in stepfamilies, a comparison with maternal reports of coparenting in firstmarriage families shows overall less coparenting behaviors in the stepfamilies. Even if cohesiveness is important in stepfamilies, fewer behaviors are actively implemented by mothers in order to strengthen it than they are in firstmarriage families. This may be understood in light of the "double agenda" partners have to face in stepfamilies: On the one hand, they have to promote the cohesiveness of their "new" family unit, but, on the other, they have to ensure that this cohesiveness does not contradict a certain degree of openness to the other family units to which their children belong. Parents in first-marriage families do not have to face this challenge and can focus on the cohesiveness of their current family unit.

In considering the predictors of coparenting and in accordance with data from previous studies, our results show that the promotion of cohesiveness is also inversely related to the age of the child (Teubert and Pinquart 2011). In first-marriage marriage families, this negative link may be viewed as functional in terms of fostering the child's autonomy; indeed, it seems logical that parents promote family cohesiveness less and less as the child gets older, as the child progressively "leaves the nest." In stepfamilies, this decrease of family integrity between the mother and father may be explained because contacts between exspouses tend to become increasingly spaced apart as the child is able to go from one home to the other alone. However, the child's age and integrity with partner are not related in stepfamilies; this may reflect the challenge mentioned earlier of being open to the "other families" of the child(ren) and at the same time building the new family cohesiveness, which is at stake regardless of the age of the child. Moreover, it could even be hypothesized that the new partners have to work even harder to promote 
cohesiveness when the child is older: The autonomy of the child may indeed be viewed as a threat to the new family unit (Papernow 2013).

Another difference between stepfamilies and first-marriage families lies in the role of marital satisfaction. In accordance with what has been described extensively in the literature, our results show that marital satisfaction is a strong predictor of family cohesiveness in first-marriage families (Cowan and Cowan 1992; Lewis 1989). On the other hand, marital satisfaction is not linked with family integrity in stepfamilies, suggesting that the marital subsystem and the coparental subsystem with the new partner are partially kept separate by the mothers. This is in line with studies showing that mothers have more realistic expectations (more pragmatic and less romantic) about their new relationship than they had in their previous marriage and consequently that their marital satisfaction tends to be higher (Hetherington and Jodl 1994). In our sample, average marital satisfaction is indeed higher in stepfamilies than in first-marriage families. However, it has been shown that the difference in marital satisfaction between first-marriage families and stepfamilies tends to recede with time (Huston et al. 2001). This tendency seemed to be confirmed by examining the number of mothers in marital distress in our sample according to the cut-off of the Marital Adjustment Test: 37 (24.7 \%) in firstmarriage families and $25(16.7 \%)$ in stepfamilies. These elevated numbers may be explained by the rather long average duration of the relationship in our families (almost 15 years in first-marriage families and 7 years in stepfamilies), showing that, in this regard, both kinds of families share the same evolution. Finally, our results also contradict some studies that showed interdependence between the adult dyads in post-divorce families (e.g., Schrodt et al. 2011), as marital satisfaction with the partner is not linked with coparenting with the father, which may also be understood as the result of a separation by the mother between the different subsystems.

Regarding the two dimensions of conflictive coparenting, there is again an effect of age, but in stepfamilies only: The older the child, the less the disparagement against the father and the more the disparagement against, and conflict with, the partner. This is another confirmation of the difficulty of ensuring cohesiveness in stepfamilies with an older child, with conflictive coparenting being more likely to occur. Marital satisfaction plays a buffering role against conflictive coparenting in first-marriage families, as has previously been described in the literature. Interestingly, it is also related to conflict and disparagement against the partner in stepfamilies, showing that marital satisfaction is related to the negative sides of coparenting in these families but not to cohesiveness-in other words, even though both subsystems may be partially separated by mothers, there is nevertheless a "spillover" effect (Fainsilber Katz and Gottman 1996) of marital dissatisfaction onto the coparental relationship. Marital satisfaction is not related to conflict and disparagement against the father in stepfamilies, which is a confirmation of the independence between the mother-partner marital subsystem and the fathermother coparental subsystem in stepfamilies.

Finally, contrary to our expectations, neither the gender of the child nor the attachment dimension of avoidance in the mother was linked to coparenting. Results of previous studies about the influence of gender have been inconsistent, and the different factors explaining why coparenting could be more conflictive when the child is a boy or when the child is a girl may have all been at work in our sample, resulting in the cancellation of their respective effects in consideration of the influence of gender at a group level. Regarding avoidance, we found only a marginal positive link with disparagement in first-marriage families; this link is consistent with the process of triangulation described in the family therapy literature (Minuchin et al. 1978). Avoidance of conflict in families may lead one (or both) parent(s) to build a coalition with the child by speaking ill of the other parent-which is exactly what disparagement refers to. Additional studies are needed to further explore the influence of attachment style in parents and, more globally, the importance of personality factors in coparenting.

In conclusion, this study shows that promoting family cohesiveness is important in stepfamilies, but in two different ways, depending on the coparent involved. Mothers may promote the family unit either with the father or with the partner, but are unlikely to do so with both. Moreover, the determinants of coparenting do not play the same role across the different coparental dyads. While marital satisfaction with the partner is related to coparenting with the partner (but for conflictive coparenting only), it is not related to coparenting with the father. In fact, the predictors that we tested (gender and age of the child, marital satisfaction with the partner, attachment style of the mother), with the exception of the age of the child, failed to explain coparenting with the father in stepfamilies. Variables relative to the divorce itself should be tested (e.g., custodial rate, which was homogeneous in our sample and so we are not able to assess its influence; the partner responsible for the decision to divorce; and the geographical distance between households) in order to have a comprehensive picture of the processes involved in ex-spouse coparenting. Globally, our results show that coparenting is active in all of its dimensions in stepfamilies, but with different determinants depending on the partner involved and when compared with first-marriage families.

The study has several limitations. First, we had to simultaneously take into account independent data 
(stepfamilies vs. first-marriage families) and dependent data (the two dyads in stepfamilies) in comparing the three coparental dyads. However, our study design could not be fit for use with hierarchical models that allow treatment of both types of data using the same procedure. Our data are indeed asymmetrical, since there is only one coparent in first-marriage families but two in stepfamilies, precluding the construction of a two-level model. We thus had to split our sample of stepfamilies into two subsamples in order to compare the three coparental dyads, with a consequential loss of statistical power. Second, coparenting data in this study are based on a self-report of coparenting behaviors by the mother and not on an assessment of her coparenting intentions or beliefs. Some items of the questionnaire refer to the number of behaviors that occurred in the presence of the child. This may explain in part the differences in coparenting, as there is a base-rate difference in the child's presence across the dyads, although all differences across dyads are not in the same direction, which shows that our results cannot be reduced to a difference in the number of contacts between the child and the coparents. Another limitation of the questionnaires is that they allowed us to know the mothers' representations of their coparenting behaviors, but not what they actually do. Systematic observation of interactions may be warranted in order to gain a more comprehensive view of coparenting from the perspective of the parents. Finally, we relied exclusively on mother-reported data. The next step would be to assess coparenting by the father in both stepfamilies and firstmarriage families and also by the partner in stepfamilies in order to obtain information from multiple informants.

Despite these limitations, this study was a first step in the systematic comparison of mother-father and motherpartner coparenting in stepfamilies and mother-father coparenting in first-marriage families, allowing us to show that the promotion of family cohesiveness is operating in stepfamilies as well as in first-marriage families.

Acknowledgments This research was supported by the Swiss National Science Foundation, Grant 100015_122413.

\section{References}

Adamsons, K., \& Pasley, K. (2006). Coparenting following divorce and relationship dissolution. In M. A. Fine \& J. H. Harvey (Eds.), Handbook of divorce and relationship dissolution (pp. 241-261). Mahwah, NJ: Erlbaum.

Amato, P. R. (1999). Diversity within single-parent families. In D. H. Demo, K. R. Allen, \& M. A. Fine (Eds.), Handbook of family diversity (pp. 149-172). New York, NY: Oxford University Press.

Amato, P. R., Loomis, L., \& Booth, A. (1995). Parental divorce, marital conflict, and offspring well-being during early adulthood. Social Forces, 73, 895-915. doi:10.1093/sf/73.3.895.
Amato, P. R., Meyers, C. E., \& Emery, R. E. (2009). Changes in nonresident father-child contact from 1976 to 2002. Family Relations, 58, 41-53. doi:10.1111/j.1741-3729.2008.00533.x.

Amato, P. R., \& Rezac, S. (1994). Contact with nonresident parents, interparental conflict, and children's behavior. Journal of Family Issues, 15, 191-207. doi:10.1177/0192513X94015002003.

Baker, J., McHale, J., Strozier, A., \& Cecil, D. (2010). Mothergrandmother coparenting relationships in families with incarcerated mothers: A pilot investigation. Family Process, 49, 165-184. doi:10.1111/j.1545-5300.2010.01316.x.

Bartholomew, K., \& Horowitz, L. M. (1991). Attachment styles among young adults: A test of a four-category model. Journal of Personality and Social Psychology, 61, 226-244. doi:10.1037/ 0022-3514.61.2.226.

Beaton, J. M., Doherty, W. J., \& Wenger, L. (2013). Mothers and fathers parenting together. In A. L. Vangelisti (Ed.), Handbook of family communication (2nd ed., pp. 225-240). New York, NY: Routledge.

Belsky, J., Crnic, K., \& Gable, S. (1995). The determinants of coparenting in families with toddler boys: Spousal differences and daily hassles. Child Development, 66, 629-642. doi:10.1111/ j.1467-8624.1995.tb00894.x.

Belsky, J., \& Hsieh, K. (1998). Patterns of marital change during the early childhood years: Parent personality, coparenting, and division-of-labor correlates. Journal of Family Psychology, 12, 511-528. doi:10.1037/0893-3200.12.4.511.

Bjarnason, T., \& Arnarsson, A. (2011). Joint physical custody and communication with parents: A cross-national study of children in 36 western countries. Journal of Comparative Family Studies, $42,871-890$.

Bouthillier, D., Tremblay, N., Hamelin, F., Julien, D., \& Sherzer, P. (1996). Traduction et validation canadienne-française d'un questionnaire évaluant l'attachement chez l'adulte [Translation and validation in Canadian-French of a questionnaire assessing adult attachment]. Canadian Journal of Behavioural Science, 28, 74-77. doi:10.1037/0008-400X.28.1.74.

Braithwaite, D. O., McBride, M. C., \& Schrodt, P. (2003). "Parent teams" and the everyday interactions of co-parenting in stepfamilies. Communication Reports, 16, 93-111. doi:10. 1080/08934210309384493.

Bray, J. H., \& Kelly, J. (1998). Stepfamilies: Love, marriage and parenting in the first decade. New York, NY: Broadway Books.

Cowan, C. P., \& Cowan, P. A. (1992). When partners become parents: The big life change for couples. Mahwah, NJ: Erlbaum.

Cowan, P. A., Cowan, C. P., \& Mehta, N. (2009). Adult attachment, couple attachment, and children's adaptation to school: An integrated attachment template and family risk model. Attachment \& Human Development, 11, 29-46. doi:10.1080/ 14616730802500222

Dopkins Stright, A., \& Neitzel, C. (2003). Beyond parenting: Coparenting and children's classroom adjustment. International Journal of Behavioral Development, 27, 31-40. doi:10.1080/ 01650250143000580.

Dozier, B. S., Sollie, D. L., \& Stack, S. J. (1993). The effects of postdivorce attachment on coparenting relationships. Journal of Divorce \& Remarriage, 19, 109-124. doi:10.1300/J087v19n03_ 08 .

Emery, R. E. (2012). Renegotiating family relationships: Divorce, child custody, and mediation (2nd ed.). New York, NY: Guilford Press.

Fainsilber Katz, L., \& Gottman, J. M. (1996). Spillover effects of marital conflict: In search of parenting and coparenting mechanisms. In J. McHale \& P. A. Cowan (Eds.), Understanding how family-level dynamics affect children's development: Studies of two-parent families (pp. 57-76). San Francisco, CA: Jossey-Bass. 
Falci, C. (2006). Family structure, closeness to residential and nonresidential parents, and psychological distress in early and middle adolescence. The Sociological Quarterly, 47, 123-146. doi:10.1111/j.1533-8525.2006.00040.x.

Favez, N., Frascarolo, F., \& Fivaz-Depeursinge, E. (2006). Family alliance stability and change from pregnancy to toddlerhood and marital correlates. Swiss Journal of Psychology, 65, 213-220. doi:10.1024/1421-0185.65.4.213.

Favez, N., Lopes, F., Bernard, M., Frascarolo, F., Lavanchy Scaiola, C., Corboz-Warnery, A., \& Fivaz-Depeursinge, E. (2012). The development of family alliance from pregnancy to toddlerhood and child outcomes at 5 years. Family Process, 51, 542-556. doi:10.1111/j.1545-5300.2012.01419.x.

Feinberg, M. E. (2003). The internal structure and ecological context of coparenting: A framework for research and intervention. Parenting: Science and Practice, 3, 95-132. doi:10.1207/ S15327922PAR0302_01.

Feinberg, M. E., \& Sakuma, K.-L. (2011). Coparenting interventions for expecting parents. In J. McHale \& K. Lindahl (Eds.), Coparenting: A conceptual and clinical examination of family systems (pp. 171-190). Washington, DC: American Psychological Association.

Frascarolo, F., Dimitrova, N., Zimmermann, G., Favez, N., KuerstenHogan, R., Baker, J., \& McHale, J. (2009). Présentation de l'adaptation française de "l'échelle de coparentage" de McHale pour familles avec jeunes enfants [Presentation of the French validation of McHale's "coparenting scale" for families with young children]. Neuropsychiatrie de l'enfance et de l'adolescence, 57, 221-226. doi:10.1016/j.neurenf.2008.11.005.

Frascarolo, F., Fivaz-Depeursinge, E., \& Favez, N. (2011). Coparenting in family-infant triads: The use of observation in systemic interventions. In J. McHale \& K. Lindahl (Eds.), Coparenting: A conceptual and clinical examination of family systems (pp. 211-230). Washington, DC: American Psychological Association.

Frosch, C., Mangelsdorf, S., \& McHale, J. L. (1998). Correlates of marital behavior at 6 months postpartum. Developmental Psychology, 34, 1438-1449. doi:10.1037/0012-1649.34.6.1438.

Ganong, L., Coleman, M., Fine, M., \& Martin, P. (1999). Stepparents' affinity-seeking and affinity-maintaining strategies with stepchildren. Journal of Family Issues, 20, 299-327. doi:10.1177/ 019251399020003001.

Gately, N. J., Pike, L. T., \& Murphy, P. T. (2006). An exploration of the impact of the family court process on "invisible" stepparents. Journal of Divorce \& Remarriage, 44, 31-52. doi:10.1300/ J087v44n03_03.

Hazan, C., \& Shaver, P. (1987). Romantic love conceptualized as an attachment process. Journal of Personality and Social Psychology, 52, 511-524. doi:10.1037/0022-3514.52.3.511.

Hetherington, E. M., \& Jodl, K. M. (1994). Stepfamilies as setting for child development. In A. Booth \& J. Dunn (Eds.), Stepfamilies. Who benefits? Who does not? (pp. 55-79). Hillsdale, NJ: Erlbaum.

Hetherington, E. M., \& Stanley-Hagan, M. S. (2002). Parenting in divorced and remarried families. In M. Bornstein (Ed.), Handbook of parenting (2nd ed., Vol. 3, pp. 233-255). Mahwah, NJ: Erlbaum.

Holroyd, R., \& Sheppard, A. (1997). Parental separation: Effects on children; implications for services. Child: Care Health and Development, 23, 369-378. doi:10.1111/j.1365-2214.1997. tb00904.x.

Huston, T. L., Caughlin, J. P., Houts, R. M., Smith, S. E., \& George, L. J. (2001). The connubial crucible: Newlywed years as predictors of marital delight, distress, and divorce. Journal of Personality and Social Psychology, 80, 237-252. doi:10.1037/ 0022-3514.80.2.237.
Kolak, A. M., \& Volling, B. L. (2007). Parental expressiveness as a moderator of coparenting and marital relationship quality. Family Relations, 56, 467-478. doi:10.1111/j.1741-3729.2007. 00474.x.

Leary, A., \& Katz, L. F. (2004). Coparenting, family-level processes, and peer outcomes: The moderating role of vagal tone. Development and Psychopathology, 16, 593-608. doi:10.1017/ S0954579404004687.

Lewis, J. (1989). The birth of the family: An empirical inquiry. New York, NY: Brunner/Maazel.

Locke, H., \& Wallace, K. (1959). Short marital adjustment and prediction tests: Their reliability and validity. Marriage and Family Living, 21, 251-255. doi:10.2307/348022.

Maccoby, E. E., \& Mnookin, R. H. (1992). Dividing the child: Social and legal dilemmas of custody. Cambridge, MA: Harvard University Press.

Madden-Derdich, D. A., \& Arditti, J. A. (1999). The ties that bind: Attachment between former spouses. Family Relations, 48, 243-249. doi: $10.2307 / 585633$.

Margolin, G., Gordis, E., \& John, R. (2001). Coparenting: A link between marital conflict and parenting in two-parents families. Journal of Family Psychology, 15, 3-21. doi:10.1037/08933200.15.1.3.

McGene, J., \& King, V. (2012). Implications of new marriages and children for coparenting in nonresident father families. Journal of Family Issues, 33, 1619-1641. doi:10.1177/0192513×12437150.

McHale, J. P. (1995). Coparenting and triadic interactions during infancy: The roles of marital distress and child gender. Developmental Psychology, 31, 985-996. doi:10.1037/00121649.31.6.985.

McHale, J. P. (1997). Overt and covert coparenting processes in the family. Family Process, 36, 183-210. doi:10.1111/j.1545-5300. 1997.00183.x.

McHale, J. P. (2007). Charting the bumpy road of coparenthood: Understanding the challenges of family life. Washington, DC: Zero to Three Press.

McHale, J. P., Khazan, I., Erera, P., Rotman, T., DeCourcey, W., \& McConnell, M. (2002a). Coparenting in diverse family systems. In M. Bornstein (Ed.), Handbook of parenting: Vol. 3. Being and becoming a parent (2nd ed., pp. 75-107). Mahwah, NJ: Erlbaum.

McHale, J. P., Lauretti, A., Talbot, J., \& Pouquette, C. (2002b). Retrospect and prospect in the psychological study of coparenting and family group process. In J. McHale \& W. Grolnick (Eds.), Retrospect and prospect in the psychological study of families (pp. 127-165). Mahwah, NJ: Erlbaum.

McHale, J. P., Rao, N., \& Krasnow, A. D. (2000). Constructing family climates: Chinese mothers' reports of their co-parenting behaviour and preschoolers' adaptation. International Journal of Behavioral Development, 24, 111-118. doi:10.1080/016502500 383548.

McHale, J. P., \& Rasmussen, J. (1998). Coparental and family grouplevel dynamics during infancy: Early family predictors of child and family functioning during preschool. Development and Psychopathology, 10, 39-58.

Mikulincer, M., \& Shaver, P. (2007). Attachment in adulthood: Structure, dynamics and change. New York, NY: Guilford Press.

Minuchin, S. (1974). Families and family therapy. Cambridge, MA: Harvard University Press.

Minuchin, S., Rosman, B., \& Baker, L. (1978). Psychosomatic families: Anorexia nervosa in context. Cambridge, MA: Harvard University Press.

Paley, B., Cox, M. J., Kanoy, K. W., Harter, K. S. M., Burchinal, M., \& Margand, N. A. (2005). Adult attachment and marital interaction as predictors of whole family interactions during the transition to parenthood. Journal of Family Psychology, 19, 420-429. doi:10.1037/0893-3200.19.3.420. 
Papernow, P. L. (2013). Surviving and thriving in stepfamily relationships: What works and what doesn't. New York, NY: Routledge.

Pasley, K., \& Garneau, C. (2012). Remarriage and stepfamily life. In F. Walsh (Ed.), Normal family processes: Growing diversity and complexity (4th ed., pp. 149-171). New York, NY: The Guilford Press.

Roberson, P. N. E., Sabo, M., \& Wickel, K. (2011). Internal working models of attachment and postdivorce coparent relationships. Journal of Divorce \& Remarriage, 52, 187-201. doi:10.1080/ 10502556.2011.569442.

Schoppe, S. J., Mangelsdorf, S. C., \& Frosch, C. A. (2001). Coparenting, family process, and family structure: Implications for preschoolers' externalizing behavior problems. Journal of Family Psychology, 15, 526-545. doi:10.1037/0893-3200.15.3. 526.

Schoppe-Sullivan, S., Mangelsdorf, S., Frosch, C., \& McHale, J. (2004). Associations between coparenting and marital behavior from infancy to the preschool years. Journal of Family Psychology, 18, 194-207. doi:10.1037/0893-3200.18.1.194.

Schrodt, P. (2010). Coparental communication with nonresidential parents as a predictor of couples' relational satisfaction and mental health in stepfamilies. Western Journal of Communication, 74, 484-503. doi:10.1080/10570314.2010.512282.

Schrodt, P., Miller, A. E., \& Braithwaite, D. O. (2011). Ex-spouses' relational satisfaction as a function of coparental communication in stepfamilies. Communication Studies, 62, 272-290. doi:10. 1080/10510974.2011.563453.

Shaver, P. R., \& Mikulincer, M. (2002a). Attachment-related psychodynamics. Attachment \& Human Development, 4, 133-161. doi:10.1080/14616730210154171.

Shaver, P. R., \& Mikulincer, M. (2002b). Dialogue on adult attachment: Diversity and integration. Attachment \& Human Development, 4, 243-257. doi:10.1080/14616730210157484.

Sheftall, A. H., Schoppe-Sullivan, S. J., \& Futris, T. G. (2010). Adolescent mothers' perceptions of the coparenting relationship with their child's father: A function of attachment security and trust. Journal of Family Issues, 31, 884-905. doi:10.1177/ $0192513 \times 09359892$.

Simpson, J. A. (1990). Influence of attachment styles on romantic relationships. Journal of Personality and Social Psychology, 59, 971-980. doi:10.1037/0022-3514.59.5.971.

Simpson, J. A., Rholes, W. S., \& Nelligan, J. S. (1992). Support seeking and support giving within couples in an anxietyprovoking situation: The role of attachment styles. Journal of
Personality and Social Psychology, 62, 434-446. doi:10.1037/ 0022-3514.62.3.434.

Stroud, C. B., Durbin, C. E., Wilson, S., \& Mendelsohn, K. A. (2011). Spillover to triadic and dyadic systems in families with young children. Journal of Family Psychology, 25, 919-930. doi:10.1037/a0025443.

Talbot, J. A., Baker, J. K., \& McHale, J. P. (2009). Sharing the love: Prebirth adult attachment status and coparenting adjustment during early infancy. Parenting, 9, 56-77. doi:10.1080/ 15295190802656760

Talbot, J. A., \& McHale, J. P. (2004). Individual parental adjustment moderates the relationship between marital and coparenting quality. Journal of Adult Development, 11, 191-205. doi:10.1023/B:JADE.0000035627.26870.f8.

Teubert, D., \& Pinquart, M. (2010). The association between coparenting and child adjustment: A meta-analysis. Parenting, 10, 286-307. doi:10.1080/15295192.2010.492040.

Teubert, D., \& Pinquart, M. (2011). The Coparenting Inventory for Parents and Adolescents (CI-PA): Reliability and validity. European Journal of Psychological Assessment, 27, 206-215. doi:10.1027/1015-5759/a000068.

Van Eeden-Moorefield, B., \& Pasley, B. K. (2013). Remarriage and stepfamily life. In G. W. Peterson \& K. R. Bush (Eds.), Handbook of marriage and the family (3rd ed., pp. 517-546). New York, NY: Springer.

Van Egeren, L. (2003). Prebirth predictors of coparenting experiences in early infancy. Infant Mental Health Journal, 24, 278-295. doi:10.1002/imhj.10056.

Van Egeren, L., \& Hawkins, D. (2004). Coming to terms with coparenting: Implications of definition and measurement. Journal of Adult Development, 11, 165-177.

Visher, E. B., Visher, J. S., \& Pasley, K. (2003). Remarriage families and stepparenting. In F. Walsh (Ed.), Normal family processes (3rd ed., pp. 153-175). New York, NY: Guilford Press.

Vogt Yuan, A. S., \& Hamilton, H. A. (2006). Stepfather involvement and adolescent well-being: Do mothers and nonresidential fathers matter? Journal of Family Issues, 27, 1191-1213. doi:10.1177/0192513X06289214.

Whiteside, M. F., \& Becker, B. J. (2000). Parental factors and the young child's postdivorce adjustment: A meta-analysis with implications for parenting arrangements. Journal of Family Psychology, 14, 5-26. doi:10.1037/0893-3200.14.1.5.

Wright, J., \& Sabourin, S. (1985). L'intervention auprès du couple [Couple intervention]. St.-Damase, Québec: Les Editions Consultation. 